\title{
Bats (Chiroptera) of the Silesian Beskid Mountains
}

\author{
Robert W. MySŁaJEK*, Korneliusz KUREK*, Czesław SzURA**, \\ Sabina NOWAK* and Piotr ORYSIAK* \\ *Association for Nature WOLF, Twardorzeczka 229, 34-324 Lipowa, Poland; e-mail: rwm@autograf.pl \\ ** Speleo Club, ul. 1 maja 45, 43-300 Bielsko-Biała,Poland; e-mail: szuracz@poczta.onet.pl
}

\begin{abstract}
During a study conducted in 2000-2007 the following 15 species of bats were recorded in the Silesian Beskid Mts. (Western Carpathians, S Poland): Rhinolophus hipposideros, Myotis myotis, M. bechsteinii, M. nattereri, M. emarginatus, M. mystacinus, M. brandtii, M. daubentonii, Vespertilio murinus, Eptesicus nilssonii, E. serotinus, Nyctalus leisleri, N. noctula, Plecotus auritus, and Barbastella barbastellus. The survey of the bat population was carried out by catching bats in nets, with the dominant species captured being $M$. daubentonii (37.0\%), P. auritus (16.0\%), M. mystacinus (11.4\%), and M. nattereri (10.4\%). Bats from the genera Eptesicus and Nyctalus were only caught on very rare occasions. The bat community found in caves consisted of seven species, mainly $R$. hipposideros $(59.7 \%)$ and M. myotis (26.7\%).
\end{abstract}

Key words: bat fauna, Carpathians, mountains, mist-netting, cave inspections

\section{INTRODUCTION}

Bats (Chiroptera) are the least studied group of mammals of the Silesian Beskid Mts. (Witkowski 1997). The first information about these animals was provided by Kowalski (1953), who recorded them in a cave in Trzy Kopce and the Malinowska Cave. The presence of bats in the same caves was subsequently confirmed by other authors (Pucek \& Raczyński 1983, Kokurewicz 1990, Wołoszyn et al. 1994). Further locations were discovered by members of a Speleo Club from Bielsko-Biała (Klassek 1990, Ganszer 1995, Pulina 1997). However, only information regarding the presence of bats, without identifying the species, was provided. The only exceptions were Rhinolophus hipposideros and Myotis myotis, which can be easily identified by non-professionals (see: Ganszer 1995, Mysłajek 2000). More detailed studies on the bat fauna in caves of the Silesian Beskid Mts. have been carried out by the Association for Nature "Wolf" since 1996 (Mysłajek 1998a, 1998b, 2002b). Nevertheless, apart from some anecdotal information (Mysłajek 2003), there is still no data published about any bat fauna outside the caves.

The aim of our study was to get a complete list of bat species living in the Silesian Beskid Mts. and to assess the proportion of these species within the bat assemblages.

\section{STUDY AREA}

Research was conducted in the Polish part of the Silesian Beskid Mountains (SBM). The area is located in the western-most part of the Polish Carpathians (N 18 $59^{\prime}-19^{\circ} 07^{\prime}$; E 49 $33^{\prime}-$ $\left.49^{\circ} 47^{\prime}\right)$, and is divided into two parts - Polish (ca $560 \mathrm{~km}^{2}$ ) and Czech (ca $\left.40 \mathrm{~km}^{2}\right)$. Most of the area is protected as a landscape park $\left(386 \mathrm{~km}^{2}\right)$ established in 1998 . There are also a few nature reserves, but they only cover $1 \%$ of the total area. A part of the Silesian Beskid Mts. was designated a Nature 2000 protected site. 
The altitude within the study area ranges from 300 to $1257 \mathrm{~m}$ a.s.l. There are 236 caves (unpublished data of the Speleo Club in Bielsko-Biała, 26.11.2006., www.speleo.bielsko.pl), with the Miecharska Cave and the Cave in Trzy Kopce being the biggest caves in the Polish Carpathians outside of the Tatry Mts. (Klassek \& Mleczek 2006).

The climate of the Silesian Beskid Mts. is mainly determined by altitude (Table 1) and is divided into three climatic zones: semi-warm (below $670 \mathrm{~m}$ a.s.1.), semi-cold (670-980 $\mathrm{m}$ a.s.l.) and cold (above $980 \mathrm{~m}$ a.s.1.) (Hess 1965). Climatic zones correlate to plant zones. The lowest of these was formerly covered by rich forests dominated by oak (Quercus sp.) and lime (Tilia sp.). Forest cover has changed extensively and is presently dominated by farmland, villages, and towns. The middle zone was originally covered by beech (Fagus sylvatica) and fir (Abies alba) with a mixture of spruce (Picea alba), while the highest zone was dominated by natural spruce forests. Currently both zones are covered mostly by planted spruce monocultures (Wilczek 1995). Large meadows are located within the forests. Some of those are still used as pasture for livestock grazing, but the rest have not been grazed for a long time, and have subsequently been naturally re-colonized by young spruce, beech, and birch (Betula pendula) trees.

Table 1. Characteristics of the climatic zones in the Silesian Beskid Mountains (according to Hess 1965).

\begin{tabular}{|l|c|c|c|c|}
\hline Climatic zones & $\begin{array}{c}\text { Average temperature } \\
{\left[{ }^{\circ} \mathrm{C}\right]}\end{array}$ & $\begin{array}{c}\text { Annual percipitation } \\
{[\mathrm{mm}]}\end{array}$ & $\begin{array}{c}\text { Snow occurence } \\
{[\text { days }]}\end{array}$ & $\begin{array}{c}\text { Length of vegetation } \\
\text { season [days] }\end{array}$ \\
\hline Cold & 2 & 1600 & 250 & 140 \\
Semi-cold & 4 & 1400 & 210 & 170 \\
Semi-warm & $6-8$ & $800-1000$ & $110-165$ & $200-220$ \\
\hline
\end{tabular}

There are numerous towns, villages, weekend cabins, and recreation centres along the forest peripheries as well as many ski lifts, ski routes, and tourist paths within the forest. Human penetration into the forest is the most intense during weekends and holidays (Mysłajek 2001a). The average density of human population is the highest in the Polish Carpathians, on average 150 inhabitants $/ \mathrm{km}^{2}$, and reaches up to 300 inhabitants $/ \mathrm{km}^{2}$ near Bielsko-Biała town (Walaszek 2002).

\section{METHODS}

We conducted research during the period 2000-2007. Our main methods for surveying the bat fauna of the Silesian Beskid Mts. (SBM) have been the capture of bats in mist nets and cave inspections. We obtained some additional data by examining buildings and old military bunkers and by using ultrasound detectors. We also checked 444 bird boxes (155 in 2002, 1 in 2003, 135 in 2004, 24 in 2005, and 129 in 2006).

We captured bats from May to October in mist-nets $(3 \times 7 \mathrm{~m}$, Ecotone, Poland) in 23 localities during 65 nights (a total of 300 hours of netting). At every point of capture we used 2-5 nets and we checked them every 10 minutes. We recorded the species of each bat as well as the reproductive status of females. In accordance with the Polish law we obtained the appropriate permission to capture bats from the Ministry of Environment.

During the study period we carried out irregular surveys of caves in the SBM. We generally checked them year-round, but mainly during autumn and winter. In total we carried out 55 visits in 28 caves. During cave checking we identified all species of bats, with the exception of morphologically very similar Myotis mystacinus and Myotis brandtii, which we counted together. We also obtained unpublished information about bats observed in caves by members of the Speleo Club in Bielsko-Biała. However, the data indicated the presence of the Rhinolophus hipposideros (which is easily recognized by non-professionals) as well as some bats not identified by members of the club. 
We also checked the Waligóra bunker in Węgierska Górka three times during the autumn of 2006 and once in February 2007. Furthermore, we obtained and checked information regarding the presence of bats in three buildings, in Brenna, Wisła and Bielsko-Biała Olszówka. We carried out an irregular survey of bats with Pettersson ultrasound detectors D220 and D-240 within the study area.

For each species location (see Appendix 1) we recorded: the place name, the code of the Universal Transverse Mercator (UTM) grid, and the elevation above sea level (in metres). To describe individuals we used the following abbreviations: $\mathrm{D}$ - species recorded by ultrasound detector, $\mathrm{N}$ - species captured by mist nets, $\mathrm{H}$ - individuals observed during hibernation, and $\mathrm{O}$ - observations of no hibernating bats.

\section{RESULTS}

In the SBM we recorded the following 15 species of bats from two families: Rhinolophidae -Rhinolophus hipposideros (Bechstein, 1800), and Vespertilionidae - Myotis myotis (Borkhausen, 1797), Myotis bechsteinii (Kuhl, 1817), Myotis nattereri (Kuhl, 1817), Myotis emarginatus (Geoffroy, 1806), Myotis mystacinus (Kuhl, 1817), Myotis brandtii (Eversmann, 1845), Myotis daubentonii (Kuhl, 1817), Vespertilio murinus Linnaeus, 1758, Eptesicus nilssonii (Keyserling et Blasius, 1839), Eptesicus serotinus (Schreber, 1774), Nyctalus leisleri (Kuhl, 1817), Nyctalus noctula (Schreber, 1774), Plecotus auritus (Linnaeus, 1758) and Barbastella barbastellus (Schreber, 1774). Bats were recorded at locations given in Appendix 1.

We recorded 13 species of bats (Table 2) during netting efforts. The most common species captured was $M$. daubentonii (37.0\%), followed by the also numerous $P$. auritus $(16.0 \%), M$. mystacinus $(11.4 \%)$ and $M$. nattereri $(10.4 \%)$. We very rarely captured bats from the genera Eptesicus and Nyctalus.

Table 2. Bats captured with mist-nets in the Silesian Beskid Mts. in 2000-2006.

\begin{tabular}{|r|l|r|r|}
\hline \multirow{2}{*}{ No. } & \multicolumn{1}{|c|}{ Species } & \multicolumn{2}{|c|}{ Captured bats } \\
\cline { 3 - 4 } & & $\mathrm{n}$ & 37.0 \\
2 & Myotis daubentonii & 266 & 16.0 \\
3 & Plecotus auritus & 115 & 11.4 \\
4 & Myotis mystacinus & 82 & 10.4 \\
5 & Myotis nattereri & 75 & 8.9 \\
6 & Myotis emarginatus & 64 & 4.9 \\
7 & Myotis myotis & 35 & 4.5 \\
8 & Rhinolophus hipposideros & 32 & 3.5 \\
9 & Myotis bechsteinii & 25 & 1.7 \\
10 & Eptesicus nilssonii & 12 & 1.4 \\
11 & Vespertilio murinus & 10 & 0.1 \\
12 & Eptesicus serotinus & 1 & 0.1 \\
13 & Nyctalus leisleri & 1 & 0.1 \\
\hline & Total & 1 & 100.0 \\
\hline
\end{tabular}

We recorded seven species inside the caves (Table 3). The bat community in this type of shelter was greatly dominated by $R$. hipposideros $(59.5 \%)$ and less numerous $M$. myotis $(26.7 \%)$. There was hardly any record of other species, with the exception of the slightly more abundant $M$. mystacinus $/ M$. brandtii group. $R$. hipposideros was also the most abundant $(67.6 \%)$ amongst bats recorded in caves by members of the Speleo Club from Bielsko-Biała (Table 4). 
Table 3. Bats recorded in caves of the Silesian Beskid Mts. by the authors, 2000-2006. Abbreviations: Rhh $-R$. hipposideros, Mym - M. myotis, Mys/Myb - M. mystacinus/M. brandtii - counted together, Par - P. auritus, Eni - E. nilssonii, Uind - unidentified bat. * - percentage calculated only for identified individuals.

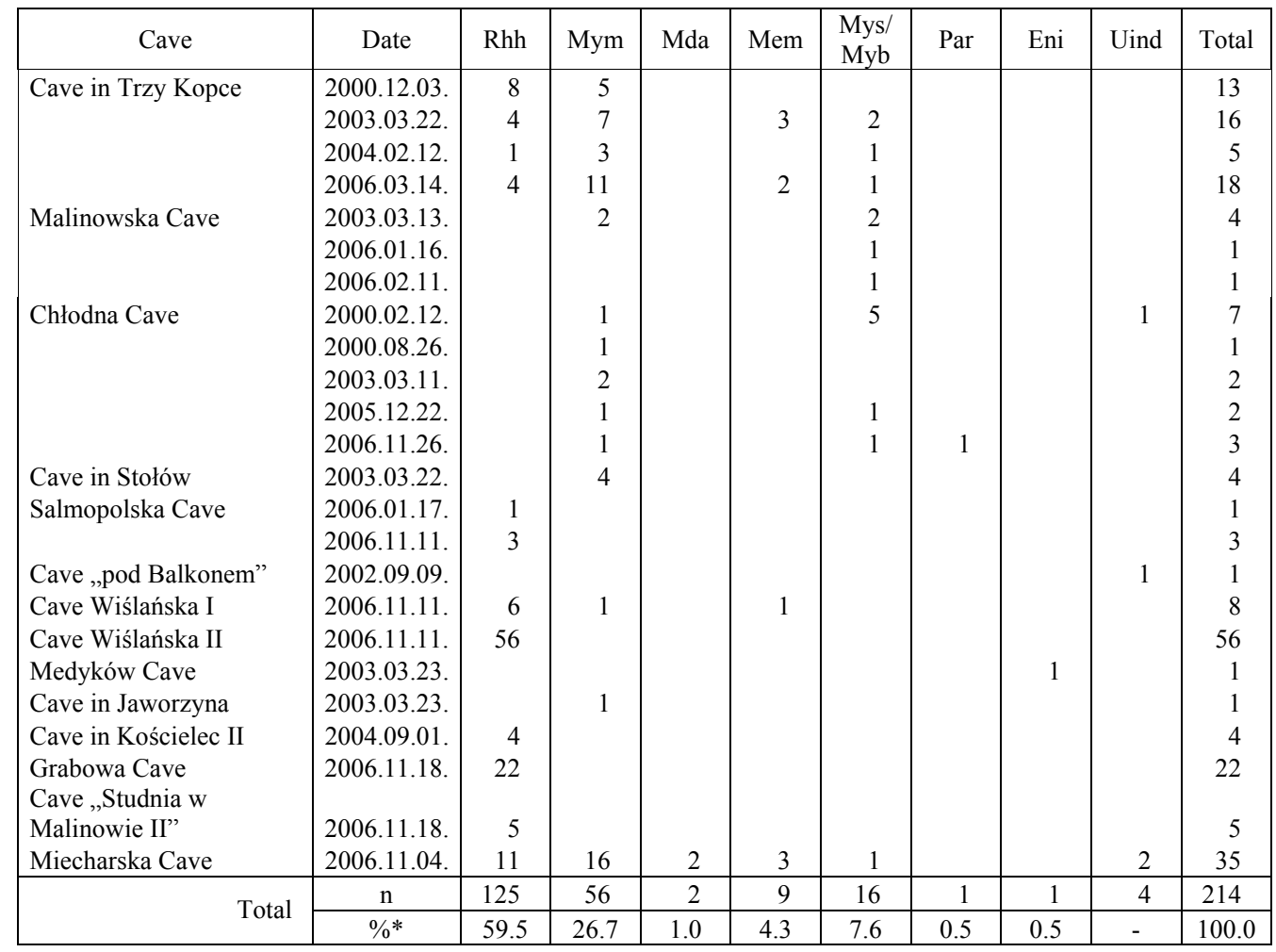

We recorded three species ( $R$. hipposideros, $V$. murinus and $B$. barbastellus) in manmade constructions, such as buildings and bunkers. We observed the following numbers of R. hipposideros in the Waligóra bunker in Węgierska Górka: on 01.09.2006 - 3 individuals, on 23.09.2006 - 4 indiv., and on 01.10.2006 - 2 indiv. This species was also observed in a wooden house in the Filipionka meadow in Brenna (1 indiv. 29.07.2006., J. Rzymełka pers. comm.). V. murinus was discovered twice in a concrete house in Bielsko-Biała Olszówka: on 29.07.2001, 1 young male was observed hanging on an outside wall near the main door, and on 18.05.2002 1 adult male was hidden in an empty plastic flowerpot on a balcony on the second floor. The same species (an adult male) was recorded on 10.03.2003 inside a concrete house in Wisła. The B. barbastellus was observed once (23.02.2007) in the Waligóra bunker in Węgierska Górka. No signs of bats were found in bird boxes we checked.

During the study period we recorded three species of bats by ultrasound detectors: $E$. serotinus, N. noctula, and M. daubentonii (for locations see Appendix 1).

Evidence of reproduction was obtained through observation of lactating females or the presence of juveniles for the following species: $R$. hipposideros, M. myotis, M. bechsteinii, M. nattereri, M. emarginatus, M. mystacinus, M. brandtii, $M$. daubentonii, $V$. murinus, $E$. nilssonii, and $P$. auritus. 
Table 4. Bats recorded in caves of the Silesian Beskid Mts. by members of the Speleoclub in Bielsko-Biała, 20002006. For abbreviations see Table 3.

\begin{tabular}{|c|c|c|c|c|c|}
\hline Cave & Date & Rhh & Uind & Total & Author \\
\hline \multirow[t]{11}{*}{ Cave in Trzy Kopce } & 08.04 .2000 & 3 & 4 & 7 & J. Ganszer, C. Szura \\
\hline & 08.12 .2001 & 1 & 3 & 4 & J. Ganszer. U. Tebin \\
\hline & 24.02 .2002 & 3 & 3 & 6 & A. Smoter, M. Smoter \\
\hline & 01.12 .2002 & 5 & 4 & 9 & J. Ganszer \\
\hline & 04.01 .2003 & 1 & 7 & 8 & A. Żera, A. Żera \\
\hline & 22.11 .2003 & 2 & 3 & 5 & J. Pukowski, G. Mołek, J. Ganszer \\
\hline & 29.11.2003. & 10 & & 10 & J. Ganszer \\
\hline & 28.12.2003. & 10 & & 10 & A. Wiculski, P. Wyrobek \\
\hline & 13.10 .2004 & 2 & 2 & 4 & J. Ganszer, A. Smoter \\
\hline & 17.02.2006 & 4 & 11 & 15 & J. Pukowski \\
\hline & 01.04 .2006 & 6 & 28 & 34 & R. Głowacki \\
\hline Cave „Studnia in Malinów II” & 23.10 .2005 & 6 & & 6 & B. Juroszek, G. Szalbot \\
\hline Cave in Malinów IV & 23.10 .2005 & 1 & & 1 & B. Juroszek, G. Szalbot \\
\hline \multirow[t]{4}{*}{ Dująca Cave } & 12.11 .2005 & 1 & & 1 & M. Pawełczyk \\
\hline & 15.11.2005. & 20 & & 20 & M. Pawełczyk \\
\hline & 02.12 .2005 & 29 & 2 & 31 & J. Ganszer \\
\hline & 12.03.2006. & 27 & 2 & 29 & R. Głowacki \\
\hline \multirow[t]{2}{*}{ Salmopolska Cave } & 20.02.2005. & 1 & & 1 & B. Juroszek \\
\hline & 20.11.2005. & 2 & & 2 & R. Głowacki \\
\hline \multirow[t]{2}{*}{ Cave in Jaworzyna } & 03.11 .2002 . & 1 & & 1 & J. Ganszer, J. Pukowski \\
\hline & 20.10 .2005 & 5 & & 5 & G. Michałek, G. Gawłowski \\
\hline Cave in Kościelec I & 12.11.2005. & 1 & & 1 & J. Ganszer, M. Ganszer \\
\hline Cave „Studnia in Kościelec” & 15.06.2003. & 1 & & 1 & A. Smoter \\
\hline Cave „pod Grzebieniem” & 13.04.2006. & 1 & 2 & 3 & J. Ganszer \\
\hline \multirow[t]{3}{*}{ Grabowa Cave } & 18.11.2004. & 18 & & 18 & B. Juroszek, P. Cieślar, J. Cieślar \\
\hline & 30.01 .2005 & 4 & & 4 & B. Juroszek \\
\hline & 21.10 .2005 & 1 & & 1 & G. Michałek, G. Gawłowski \\
\hline Cave in Skrzyczne I & 26.04 .2004 & 1 & & 1 & U. Król, P. Beczała, L. Ostrawski \\
\hline Cave in Malinów III & 13.10.2003. & & 1 & 1 & U. Król, P. Beczała \\
\hline \multirow[t]{3}{*}{ Cave „Głęboka” in Stołów } & 06.11 .2005 & & 1 & 1 & K. Krzysteczko, M. Bieniek \\
\hline & 12.11 .2005 & & 3 & 3 & $\begin{array}{l}\text { M. Jaśkiewicz, M. Pieniek, K. } \\
\text { Krzysteczko }\end{array}$ \\
\hline & 25.02 .2006 & & 2 & 2 & J. Drąg, E. Pocha, R. Muzyczka \\
\hline \multirow{2}{*}{$\begin{array}{l}\text { Cervice in Klimczok } \\
\text { Zwietrzała Cave }\end{array}$} & 20.10 .2003 & & 1 & 1 & U. Król, P. Beczała \\
\hline & 19.08.2000. & & 1 & 1 & $\begin{array}{l}\text { J. Pukowski, J. Ganszer. E. } \\
\text { Chylaszczek }\end{array}$ \\
\hline \multirow{2}{*}{ Total } & $\mathrm{n}$ & 167 & 80 & 247 & \\
\hline & $\%$ & 67.6 & 32.4 & 100.0 & \\
\hline
\end{tabular}

\section{DISCUSSION}

Although there are 24 species of bats in Poland (Sachanowicz et al. 2006), the bat fauna of the Silesian Beskid Mts. includes only $63 \%$ of them. On the other hand, we may expect the presence of Plecotus austriacus, because it was recorded in areas adjacent to the SBM (Rehák 1998, Danko et al. 2003, Mysłajek et al. 2004).

The composition of the bat community in our study area, which we recorded with the help of mist-nets, is quite similar to those determined by netting in the Beskid Mały Mts. (Mysłajek 2002a), the Pieniny Mts. (Paszkiewicz et al. 1998), and the Beskid Sądecki Mts. and Beskid Niski Mts. (Węgiel et al. 2004). This is due to the strong domination of a couple of species $M$. daubentonii and the $P$. auritus, which constitute $40-68 \%$ of all captured individuals. The most distinct bat community is in the Pieniny Mts. (Paszkiewicz et al. 1998), with a large share of M. myotis and the Pipistrellus pipistrellus. The latter species has been never caught with nets in any other parts of the Polish Carpathians (Mysłajek 2002a, Wegiel et al. 2004, this study). 
In spite of the results of the bat capture study in the Pieniny Mts. (Paszkiewicz et al. 1998), there is a visible difference between bat communities in the mountains and those in the lowlands of Poland. The most important difference is the very low number or even absence of taxa belonging to the Pipistrellus and Nyctalus genera in mountainous areas, which are quite important members of the bat population in lowland regions (Rachwald et al. 2001, Ciechanowski 2002, Mysłajek et al. 2005). This phenomenon requires more studies.

The bat community hibernating in the caves of the SBM is very similar to those observed in similar shelters in other parts of the Polish Carpathians outside of the Tatry Mts. (Mleczek et al. 1994, Mleczek 2002), and is dominated by R. hipposideros and M. myotis. Bat communities in caves in other parts of our country are more diverse (Piksa \& Nowak 2000, Weggiel et al. 2001, Kowalski et al. 2002, Gottfried et al. 2003). The same applies to bat communities hibernating in man-made structures, both in mountain (Mleczek et al. 1994, Mleczek 2002) and lowland regions (Lesiński \& Kowalski 2002, Lesiński 2006).

Bats frequently inhabit both bird and bat boxes in the lowland regions of Poland (Kowalski \& Lesiński 1994, Kasprzyk \& Ruczyński 2001, Ciechanowski 2005, Lesiński 2006), but we have not recorded their presence in this type of shelter in the SBM. In our opinion it may be caused by competition with glirids (Gliridae), which are often recorded in bird boxes within the study area (Mysłajek \& Nowak 2003).

Among the taxa we recorded in the SBM, $R$. hipposideros, M. bechsteinii, M. emarginatus, $V$. murinus, E. nilssonii and $N$. leisleri are included in the Polish Red Data Book (Wołoszyn 2001a, 2001b, 2001c, 2001d, 2001e, 2001f). Some of these are quite numerous (see Tables 1, 2) which shows how important the SBM area is for their conservation. Such an important hibernacula needs to obtain a proper legal status (e.g. caves: Grabowa, Miecharska, Wiślańska I and II), and the proposed borders of the Silesian Beskid Mts. Nature 2000 site should be extended to protect this area. Equally important is the implementation of forest management rules to protect old-growth forests and cave surroundings. During our research we recorded some cases of forest workers carrying out logging next to caves, piling tree branches by cave entrances, and burning them. The interiors of caves should also be protected against uncontrolled penetration and devastation (Mysłajek 2001b).

\section{ACKNOWLEDGMENTS}

This study was supported by the budget of the Association for Nature "Wolf" and partly by a grant from the Global Environmental Facility/Small Grant Program. The International Fund for Animal Welfare provided us with bat detectors. Many volunteers helped us during the project, and we are particularly grateful to M. Figura, M. Knapik and K. Płomińska. We would also like to thank Dr. J. Rzymełka for his information about bats, and H. Mullett and N. Owens for linguistic advice.

\section{REFERENCES}

CIECHANOWSKI M. 2002. Community structure and activity of bats (Chiroptera) over different water bodies. Mammalian Biology 67: 276-285.

CiechanowsKi M. 2005. Utilization of artificial shelters by bats (Chiroptera) in three different types of forest. Folia Zoologica 54 (1-2): 31-37.

DANKo Š., PJENČÁK P. \& MATIS Š. 2003. Netopiere Beskydského predhoria, Laboreckiej a Ondavskej vrchoviny. Vespertilio, Zwolen, 7: 97-119.

GANSZER J. 1995. Występowanie nietoperzy w jaskiniach beskidzkich w latach 1992-1994. Zacisk. Biuletyn informacyjny Klubu Taternictwa Jaskiniowego, Bielsko Biała, 11: 37.

Gottfried T., Szkudlarek R., PAszkiewicz R. \& CieŚlak M. 2003. Chiropterofauna Gór Sowich - zimowe stanowiska nietoperzy. Nietoperze, Wrocław, 4: 61-74.

HESS M. 1965. Piętra klimatyczne w polskich Karpatach Zachodnich. Zeszyty Naukowe Uniwersytetu Jagiellońskiego 115, Prace Geograficzne 11: 1-267. 
KASPRZYK K. \& RUCZYŃSKI I. 2001. The structure of bat communities roosting in bird nest boxes in two pine monocultures in Poland. Folia Zoologica 50 (2): 107-116.

KLASSEK G. 1990. Inwentarz jaskiń Polskich Karpat Fliszowych. VI. Klub Taternictwa Jaskiniowego, Polskie Towarzystwo Turystyczno Krajoznawcze, Bielsko-Biała, 88 pp.

KLAsseK G. \& MLECZeK T. 2006. Exploration of caves in the Polish outer Carpathians in the past and nowadays. In: URBAN J. (ed.), 9th International Symposium on Pseudokarst, 24-26th May 2006, Bartkowa - Beskidy Mts., Poland, pp. 55-58. Instytut Ochrony Przyrody PAN, Kraków, 85 pp.

KOKUREWICZ T. 1990. The decrease in abundance of the Lesser horseshoe bat Rhinolophus hipposideros Bechstein, 1800 (Chiroptera: Rhinolophidae) in winter quarters in Poland. Myotis 28: 109-118.

KOWALSKI K. 1953. Materiały do rozmieszczenia i ekologii nietoperzy jaskiniowych w Polsce. Fragmenta Faunistica Musei Zoologici Polonici 6, 21: 541-567.

KOWALSKI M. \& LESIŃSKI G. 1994. Bats occupying nest boxes for birds and bats in Poland. Nyctalus (N. F.) 5: 19-26.

KOWALSKI M., LESIŃSKI G. \& IGNACZAK M. 2002. Zimowy monitoring nietoperzy w jaskiniach na Wyżynie Wieluńskiej w latach 1981-1999. Nietoperze, Wrocław, 3: 119-128.

LESIŃSKI G. 2006. Wpływ antropogenicznych przekształceń krajobrazu na strukturę i funkcjonowanie zespołów nietoperzy w Polsce. Wydawnictwo SGGW, Warszawa, 212 pp.

LESIŃSKi G. \& KowALSKi M. 2002. Zimowy monitoring w Dolinie Narwi i Biebrzy w latach 1992-1999. Nietoperze, Wrocław, 3, 1: 53-60.

MLECZEK T. 2002. Zimowe spisy nietoperzy na Pogórzu Karpackim w latach 1993-1999. Nietoperze, Wrocław, 3: $163-169$.

Mleczek T., Szatkowski B. \& WęGiel W. 1994. Zimowe spisy nietoperzy w Beskidzie Niskim i Pogórzu. In: WoŁoszYN B. W. (ed.), Zimowe spisy nietoperzy w Polsce 1988-1992. Wyniki i ocena skuteczności, pp. 123129. Chiropterological Information Centre ISEZ PAN, Kraków, 230 pp.

MYSŁAJEK R. W. 1998a. Nowe stanowisko podkowca małego Rhinolophus hipposideros w Beskidzie Śląskim. Przegląd Przyrodniczy 9, 3: 130-131.

MYSŁAJEK R. W. 1998b. Zimowe spisy nietoperzy (Chiroptera) w wybranych jaskiniach województwa bielskiego w latach 1996-1997. Zacisk. Biuletyn informacyjny Klubu Taternictwa Jaskiniowego, Bielsko Biała, 13: 21-22.

MYSŁAJEK R. W. 2000. Nowe informacje o nietoperzach jaskiń Beskidu Śląskiego i Żywieckiego. Zacisk. Biuletyn informacyjny Klubu Taternictwa Jaskiniowego, Bielsko Biała, 17: 17.

MYSŁAJEK R. W. 2001a. Możliwości rozwoju różnych form turystyki w zachodniej części Karpat - na przykładzie Nadleśnictwa Węgierska Górka. Przegląd Przyrodniczy 12: 115-126.

MYSŁAJEK R. W. 2001b. Jaskinia w Trzech Kopcach w Beskidzie Śląskim - zdewastowany pomnik przyrody. Przyroda Górnego Śląska, Katowice, 26: 4.

MysŁajeK R. W. 2002a. Nietoperze Chiroptera Parku Krajobrazowego Beskidu Małego. Nietoperze, Wrocław, 2: 263-269.

MYSŁAJEK R. W. 2002b. Nietoperze jaskiń Beskidu Śląskiego - wstępne wyniki badań. Nietoperze, Wrocław, 3: $171-175$.

MYSŁAJEK R. W. 2003. Nietoperze Chiroptera parków krajobrazowych Beskidów Zachodnich - stan poznania, zagrożenia i propozycje ochrony. In: BRODA M. \& MASTAJ J. (eds), Wybrane gatunki zagrożonych zwierząt na terenie parków krajobrazowych w Beskidach, pp. 20-23. Zespół Parków Krajobrazowych Województwa Śląskiego, Będzin, 48 pp.

MYSŁAJEK R. W. \& NOWAK S. 2003. Występowanie gryzoni z rodziny popielicowatych Gliridae na terenie parków krajobrazowych Beskidów Zachodnich i możliwości ich ochrony. In: BRODA M. \& MASTAJ J. (eds), Wybrane gatunki zagrożonych zwierząt na terenie parków krajobrazowych w Beskidach, pp. 40-45. Zespół Parków Krajobrazowych Województwa Śląskiego, Będzin, 48 pp.

MYSŁAJEK R. W., NOWAK S. \& KUREK K. 2004. Fauna nietoperzy Kotliny Żywieckiej. Chrońmy Przyrodę Ojczystą 3: $78-85$.

MysŁajek R. W., Henel K., Kurek K., Urban R. \& NowaK S. 2005. Fauna nietoperzy Parku Krajobrazowego „Cysterskie Kompozycje Krajobrazowe Rud Wielkich”. Scripta Rudensia, Rudy, 14: 5-14.

PaszkieWicz R., SzKudlareK R., WĘGiel A., WęGiel J. \& WęGiel W. 1998. Materiały do chiropterofauny Pienin letnie stanowiska nietoperzy. Pieniny - Przyroda i Człowiek, Krościenko, 5: 31-46.

PIKSA K. \& NOWAK J. 2000. The bat fauna of the Polish Tatra caves. In: WOlOSZYN B. W. (ed.), Proceedings of the VIIIth EBRS, Vol. 1: 181-190. Chiropterological Information Centre ISEZ PAN, Kraków, 274 pp.

PUCEK Z. \& RACZYŃSKI J. (eds). 1983. Atlas rozmieszczenia ssaków w Polsce. PWN, Warszawa, 188 pp.

Pulina M. (ed.). 1997. Jaskinie Polskich Karpat Fliszowych. 1. Jaskinie Pogórza Śląskiego, Beskidu Śląskiego, Kotliny Żywieckiej, Beskidu Żywieckiego. Polskie Towarzystwo Przyjaciół Nauk o Ziemi, Warszawa, 250 pp.

RACHWALD A., BORATYŃSKi P. \& NOWAKOWSKI W. K. 2001. Species composition and activity of bats flying over rivers in the Białowieża Primeval Forest. Acta Theriologica 46: 235-242.

REHÁK Z. 1998. Faunistický přehled netopýrů moravsko-slezské části Karpat (Česká republika) I. Vespertilio, Zwolen, 3: $111-130$.

Sachanowicz K., Ciechanowski M. \& PiKsa K. 2006. Distribution patterns, species richness and status of bats in Poland. Vespertilio, Zwolen, 9-10: 151-173. 
WALASZEK B. (ed.). 2002. Rocznik statystyczny województwa śląskiego. Urząd Statystyczny w Katowicach, Katowice, $267 \mathrm{pp}$.

Węgiel A., GrZyWiński W., AdAmus P., SAdOWy R. \& WieCzoreK M. 2001. Nietoperze (Chiroptera) zimujące w jaskiniach Wyżyny Krakowskiej. Nietoperze, Wrocław, 2, 1: 23-42.

Węgiel A., SzkudLAReK R. \& GotTFried T. 2004. Species composition, activity and population structure of bats netted in summer at the entrances of some caves in Beskidy Mts. Nietoperze, Wrocław, 5, 1-2: 95-105.

WILCZEK Z. 1995. Zespoły leśne Beskidu Śląskiego i zachodniej części Beskidu Żywieckiego na tle zbiorowisk leśnych Karpat Zachodnich. Prace Naukowe Uniwersytetu Śląskiego, Katowice, 1490, 132 pp.

WITKOWSKI Z. 1997. Stan poznania, zagrożenia i ochrona fauny województwa bielskiego. In: MIKOŁAJSKI J. \& SOŁTYSIK J. (eds). Przyroda województwa bielskiego, pp. 139-191. Colgraf Press, Poznań, 280 pp.

WoŁoszYN B. W. 2001a. Rhinolophus hipposideros. In: GŁOwACIŃsKi Z. (ed.), Polska Czerwona Księga Zwierząt. Kręowce, pp. 46-48. PWRiL, Warszawa, 452 pp.

WoŁoszYN B. W. 2001b. Myotis bechsteinii. In: GŁowACIŃSKi Z. (ed.), Polska Czerwona Księga Zwierząt. Kręgowce, pp. 49-50. PWRiL, Warszawa, 452 pp.

WoŁosZYN B. W. 2001c. Myotis emarginatus. In: GŁOWACIŃSKi Z. (ed.),. Polska Czerwona Księga Zwierząt. Kręgowce, pp. 53-54. PWRiL, Warszawa, 452 pp.

WoŁoszYN B. W. 2001d. Vespertilio murinus. In: GŁowACiŃSKi Z. (ed.), Polska Czerwona Księga Zwierząt. Kręgowce, pp. 55-56. PWRiL, Warszawa, 452 pp.

WoŁosZYN B. W. 2001e. Eptesicus nilssonii. In: GŁOWACiŃSKI Z. (ed.), Polska Czerwona Księga Zwierząt. Kręgowce, pp. 58-59. PWRiL, Warszawa, 452 pp.

WoŁosZYN B. W. 2001f. Nyctalus leisleri. In: GŁOWACIŃSKi Z. (ed.). Polska Czerwona Księga Zwierząt. Kręgowce, pp. 58-59. PWRiL, Warszawa, 452 pp.

Woloszyn B. W., GaŁosz W., Labocha M. \& PostaWa T. 1994. Wstępne wyniki badań nietoperzy w województwie bielskim oraz postulaty ich ochrony. Chrońmy Przyrodę Ojczystą, Kraków, 3: 94-102.

\section{STRESZCZENIE}

\section{[Nietoperze (Chiroptera) Beskidu Śląskiego]}

Podczas badań prowadzonych w latach 2000-2007, na obszarze Beskidu Śląskiego (zachodnia część Karpat) stwierdzono 15 gatunków nietoperzy. Były to: podkowiec mały Rhinolophus hipposideros, nocek duży Myotis myotis, nocek Bechsteina M. bechsteinii, nocek Natterera M. nattereri, nocek orzęsiony M. emarginatus, nocek wąsatek M. mystacinus, nocek Brandta $M$. brandtii, nocek rudy M. daubentonii, mroczek posrebrzany Vespertilio murinus, mroczek pozłocisty Eptesicus nilssonii, mroczek późny E. serotinus, borowiaczek Nyctalus leisleri, borowiec wielki $N$. noctula, gacek brunatny Plecotus auritus i mopek Barbastella barbastellus. W zespole nietoperzy odławianych za pomocą japońskich sieci dominował nocek rudy $(37,0 \%)$, gacek brunatny $(16,0 \%)$, nocek wąsatek $(11,4 \%)$ oraz nocek Natterera $(10,4 \%)$. Jedynie sporadycznie odławiano nietoperze z rodzajów Eptesicus i Nyctalus. W jaskiniach Beskidu Śląskiego hibernowało 7 gatunków nietoperzy, wśród których przeważały podkowiec mały $(59,5 \%)$ i nocek duży $(26,7 \%)$.

\section{Accepted: 18 May 2007}

\section{APPENDIX 1.}

\section{Locations of bat species in the Silesian Beskid Mts.}

Rhinolophus hipposideros: (1) Cave in Trzy Kopce (H), in the front of the Cave in Trzy Kopce (N) [CA51, 970 m a.s.1.]; (2) proposed nature reserve "Kościelec" (N), Cave in Kościelec II (O), Cave "Studnia w Kościelcu" (H) [CA50, 1000 m a.s.1.]; (3) Skrzyczne - Zbójecki Ravine (N) [CA50, $880 \mathrm{~m}$ a.s.1.]; (4) Cave in Stołów (H), in the front of the Cave in Stołów (N) [CA51, $988 \mathrm{~m}$ a.s.1.]; (5) nature reserve "Kuźnie" (N) [CA50, $980 \mathrm{~m}$ a.s.1.]; (6) Bunker "Waligóra" in Węgierska Górka (O) [CV69, 460 m a.s.l.]; (7) Salmopolska Cave (H) [CA50, $902 \mathrm{~m}$ a.s.1.]; (8) Wiślańska Cave I, Wiślańska Cave II (H) [CA50, 870 m a.s.1.]; (9) Grabowa Cave (H) [CA50, 870 m a.s.1.]; (10) Cave "Studnia w Malinowie II" (H) [CA50, 1029 m a.s.1.]; (11) Miecharska Cave (H) [CA50, 964 m a.s.l.]; (12) Cave in Jaworzyna (H) [CA50, 1030 $\mathrm{m}$ a.s.1.]; (13) Cave in Malinów IV (H) [CA50, $1030 \mathrm{~m}$ a.s.1.]; (14) Cave in Skrzyczne I (H) [CA50, $880 \mathrm{~m}$ a.s.1.]; (15) Cave "nad Grzebieniem" [CA50, 1060 m a.s.1.], (16) Brenna - meadow Filipionka (O) [CA50, 750 m a.s.1.]. 
Myotis myotis: (1) Cave in Stołów (H), in the front of the Cave in Stołów (N) [CA51, 988 m a.s.1.]; (2) Cave in Trzy Kopce $(\mathrm{H})$, in the front of the Cave in Trzy Kopce (N) [CA51, 970 m a.s.1.]; (3) proposed nature reserve "Kościelec" (N) [CA50, $1000 \mathrm{~m}$ a.s.1.]; (4) nature reserve "Kuźnie" (N), Chłodna Cave (H) [CA50, $980 \mathrm{~m}$ a.s.l.]; (5) Ostre - stream in the forest compartment 69 (N) [CA60, 555 m a.s.1.]; (6) Skrzyczne - Zbójecki Ravine (N) [CA50, 880 m a.s.1.]; (7) Malinowska Cave (H) [CA50, 1020 m a.s.1.]; (8) Salmopolska Cave (H) [CA50, 902 m a.s.1.]; (9) Wiślańska Cave I (H) [CA50, 870 m a.s.1.]; (10) Cave in Jaworzyna (H) [CA50, $1030 \mathrm{~m}$ a.s.1.]; (11) Miecharska Cave (H) [CA50, $964 \mathrm{~m}$ a.s.l.].

Myotis bechsteinii: (1) in the front of the Cave in Trzy Kopce (N) [CA51, $970 \mathrm{~m}$ a.s.1.]; (2) proposed nature reserve „Kościelec“ (N) [CA50, $1000 \mathrm{~m}$ a.s.1.]; (3) nature reserve "Kuźnie” (N) [CA50, $980 \mathrm{~m}$ a.s.1.]; (4) Ostre - stream in the forest compartment 20 (N) [CA60, 540 m a.s.1.]; (5) Skrzyczne - Zbójecki Ravine (N) [CA50, 880 m a.s.l.].

Myotis nattereri: (1) proposed nature reserve „Kościelec“ (N) [CA50, 1000 m a.s.l.]; (2) nature reserve "Kuźnie” (N) [CA50, $980 \mathrm{~m}$ a.s.1.]; (3) in the front of the Dująca Cave (N) [CA51, $996 \mathrm{~m}$ a.s.1.]; (4) in the front of the Cave in Trzy Kopce (N) [CA51, $970 \mathrm{~m}$ a.s.1.]; (5) in the front of the Cave in Stołów (N) [CA51, $988 \mathrm{~m}$ a.s.1.].

Myotis emarginatus: (1) Cave in Trzy Kopce (H), in the front of the Cave in Trzy Kopce (N) [CA51, 970 m a.s.1.]; (2) in the front of the Cave in Stołów (N) [CA51, $988 \mathrm{~m}$ a.s.1.]; (3) in the front of the Dująca Cave (N) [CA51, $996 \mathrm{~m}$ a.s.l.]; (4) nature reserve "Kuźnie" (N) [CA50, 980 m a.s.1.]; (5) Skrzyczne - Zbójecki Ravine (N) [CA50, 880 m a.s.l.]; (6) Twardorzeczka - road in the forest compartment 83 (N) [CV59, $820 \mathrm{~m}$ a.s.l.]; (7) Wiślańska Cave I (H) [CA50, $878 \mathrm{~m}$ a.s.1.]; (8) Miecharska Cave (H) [CA50, $964 \mathrm{~m}$ a.s.1.].

Myotis mystacinus: (1) Ostre - stream in the forest compartment 20 (N) [CA60, $540 \mathrm{~m}$ a.s.1.]; (2) Bielsko-Biała Wapieniczanka stream (N) [CA51, $440 \mathrm{~m}$ a.s.1.]; (3) Twardorzeczka - road in the forest compartment 83 (N) [CV59, 820 m a.s.1.]; (4) in the front of the Cave in Stołów (N) [CA51, 988 m a.s.1.]; (5) in the front of the Cave in Trzy Kopce (N) [CA51, $970 \mathrm{~m}$ a.s.1.]; (6) Ostre - stream in the forest compartment 69 (N) [CA60, $555 \mathrm{~m}$ a.s.1.]; (7) proposed nature reserve "Kościelec" (N) [CA50, $1000 \mathrm{~m}$ a.s.1.]; (8) nature reserve "Kuźnie" (N) [CA50, $980 \mathrm{~m}$ a.s.1.]; (9) Szczyrk - Godziszczanka stream (N) [CA50, $560 \mathrm{~m}$ a.s.1.].

Myotis brandtii: (1) Bielsko-Biała - Wapieniczanka stream (N) [CA51, $440 \mathrm{~m}$ a.s.1.]; (2) in the front of the Cave in Stołów (N) [CA51, $988 \mathrm{~m}$ a.s.1.]; (3) in the front of the Cave in Trzy Kopce (N) [CA51, $970 \mathrm{~m}$ a.s.1.]; (4) Ostre stream in the forest compartment $69(\mathrm{~N})$ [CA60, $555 \mathrm{~m}$ a.s.1.]; (5) proposed nature reserve „Kościelec“ (N) [CA50, $1000 \mathrm{~m}$ a.s.1.]; (6) Ostre - stream in the forest compartment 20 (N) [CA60, $540 \mathrm{~m}$ a.s.1.]; (7) nature reserve "Kuźnie" (N) [CA50, $980 \mathrm{~m}$ a.s.1.].

Myotis mystacinus/Myotis brandtii complex (counted together during hibernation): (1) Cave in Trzy Kopce (H) [CA51, 970 m a.s.1.]; (2) Malinowska Cave (H) [CA50, 1020 m a.s.1.]; (3) Chłodna Cave (H) [CA50, 980 m a.s.1.]; (4) Miecharska Cave (H) [CA50, $964 \mathrm{~m}$ a.s.1.].

Myotis daubentonii: (1) Miecharska Cave (H) [CA50, $964 \mathrm{~m}$ a.s.1.]; (2) Bielsko-Biała - Wapieniczanka stream (N) [CA51, $440 \mathrm{~m}$ a.s.1.]; (3) in the front of the Cave in Stołów (N) [CA51, $988 \mathrm{~m}$ a.s.1.]; (4) in the front of the Cave in Trzy Kopce (N) [CA51, 970 m a.s.1.]; (5) proposed nature reserve "Kościelec" (N) [CA50, 1000 m a.s.l.]; (6) nature reserve "Kuźnie" (N) [CA50, $980 \mathrm{~m}$ a.s.1.]; (7) Ostre - stream in the forest compartment 20 (N) [CA60, $540 \mathrm{~m}$ a.s.1.]; (8) Ostre - stream in the forest compartment 69 (N) [CA60, $555 \mathrm{~m}$ a.s.1.]; (9) Bielsko-Biała - Wapienica, artificial lake Wielka Łąka (D) [CA51, 475 m a.s.1.]; (10 Skrzyczne - Zbójecki Ravine (N) [CA50, 880 m a.s.1.].

Vespertilio murinus: (1) Ostre - stream in the forest compartment 20 (N) [CA60, $540 \mathrm{~m}$ a.s.1.]; (2) Bielsko-Biała Olszówka Street No. 141 (O) [CA51, 450 m a.s.1.]; (3) Wisła - Kuriadty Street No. 14 (O) [CA40, 460 m a.s.1.].

Eptesicus nilssonii: (1) in the front of the Cave in Stołów (N) [CA51, 988 m a.s.1.]; (2) Skrzyczne - Zbójecki Ravine (N) [CA50, $880 \mathrm{~m}$ a.s.1.]; (3) proposed nature reserve "Kościelec" (N) [CA50, $1000 \mathrm{~m}$ a.s.1.]; (4) Ostre - stream in the forest compartment 20 (N) [CA60, 540 m a.s.1.]; (5) nature reserve "Kuźnie" (N) [CA50, 980 m a.s.1.]; (6) Medyków Cave (H) [CV59, $1000 \mathrm{~m}$ a.s.l.].

Eptesicus serotinus: (1) Ostre - stream in the forest compartment 20 (N) [CA60, $540 \mathrm{~m}$ a.s.1.]; (2) Szczyrk Godziszczanka stream (D) [CA50, $560 \mathrm{~m}$ a.s.1.].

Nyctalus leisleri: (1) Ostre - stream in the forest compartment 20 (N) [CA60, $540 \mathrm{~m}$ a.s.1.].

Nyctalus noctula: (1) Bielsko-Biała - Wapienica, artificial lake Wielka Łąka (D) [CA51, 475 m a.s.1.]; (2) Glinne (D) [CV69, 1034 m a.s.1.]; (3) Wysznia (D) [CV59, $930 \mathrm{~m}$ a.s.1.].

Plecotus auritus: (1) Twardorzeczka - stream in the forest compartment 96 (N) [CA60, 590 m a.s.1.]; (2) Twardorzeczka - road in the forest compartment 83 (N) [CV59, 820 m a.s.1.]; (3) in the front of the Dujaca Cave (N) [CA51, 996 m a.s.1.]; (4) in the front of the Cave in Stołów (N) [CA51, $988 \mathrm{~m}$ a.s.1.]; (5) Cave in Trzy Kopce (H), in the front of the Cave in Trzy Kopce (N) [CA51, 970 m a.s.1.]; (6) Skrzyczne - Zbójecki Ravine (N) [CA50, $880 \mathrm{~m}$ a.s.1.]; (7) Ostre - stream in the forest compartment 69 (N) [CA60, $555 \mathrm{~m}$ a.s.1.]; (8) proposed nature reserve "Kościelec" (N) [CA50, 1000 m a.s.1.]; (9) nature reserve "Kuźnie" (N), Cave Chłodna (H) [CA50, 980 m a.s.1.].

Barbastella barbastellus: (1) ) Bunker "Waligóra" in Węgierska Górka (H) [CV69, 460 m a.s.1.]. 